\title{
Bibliometry of Panama publications in the Science Citation Index Expanded: publication type, language, fields, authors and institutions
}

\author{
Julián Monge-Nájera ${ }^{1} \&$ Yuh-Shan $\mathrm{Ho}^{2 *}$ \\ 1. Laboratorio de Ecología Urbana, Vicerrectoría de Investigación, Universidad Estatal a Distancia, 2050 San José, Costa \\ Rica; julianmonge@gmail.com \\ 2. Trend Research Centre, Asia University, Taichung 41354, Taiwan; ysho@asia.edu.tw \\ * Correspondence
}

Received 04-II-2015. Corrected 25-V-2015. Accepted 11-VI-2015.

\begin{abstract}
Panama is a small Central American country for which apparently there are no specific scientometric studies. We analyzed 4854 research documents originating in Panama in the Science Citation Index Expanded (SCI-EXPANDED). Most are formal articles and nearly all are in English. The main fields are ecology, botany, zoology, evolution and aquatic biology. Most collaboration is done with USA, Germany, United Kingdom, Canada, and Brazil and the largest numbers of articles are published by the Smithsonian Tropical Research Institute, the University of Panama, the Gorgas Institute, the Children's Hospital, the Institute of Scientific Research and Advanced Technology Services, the Technological University of Panama, the Ministry of Health, and the University of Chiriquí. Keyword terms show a concentration on tropical forest trees, diversity and variation, considering mostly the effects of particular physical and biological causes. Output has grown steadily for several decades and continues to grow. The SCI-EXPANDED citations remain relatively stable and the lifespan of articles exceeds 20 years, with top citation four years after publication. The Impact Factor as currently measured is not appropriate to know the impact of Panamanian research. Our results only apply to the literature in the SCI-EXPANDED. Panama has nearly 100 scientific journals that are not taken into account by the SCI-EXPANDED. Thus the full productivity of authors and institutions, and their impact, remain to be studied, but our data represent a valid baseline for future research. Rev. Biol. Trop. 63 (4): 1255-1266. Epub 2015 December 01.
\end{abstract}

Key words: Panama, SCI-EXPANDED, Web of Science, Research Trend.

Panama is a small Central American country with four out of ten people living in poverty (United Nations Organization: http://goo. gl/1aIgb9) but with an extraordinary world visibility thanks to the Panama Canal. The small population (3 864000 inhabitants) has a per capita Gross Domestic Product of $\$ 11$ 000. As in other ex-colonies of Spain, scientific development in Panama was minimal until the Nineteenth Century (Castillero, 2004), but the number of articles published by Panamanian institutions and authors has been growing steadily in the last decades (Barreto et al., 2012). After 1880 there was a significant scientific interest in the country because the French
Panama Canal Company needed to control the lethal effect of tropical parasites that affected its workers; however most scientific work at the time was done by foreign researchers (Castillero, 2004).

Like in the rest of Central America, the early Twentieth Century was marked by a new generation of local students who travelled to Europe and the USA to train in practical fields such as medicine and agriculture. Exposed to the progressive ideas that they met in those countries they returned to Panama and founded the first national research programs, mostly in clinical medicine and agriculture; this led to the development of three main fields including 
parasitology, botany, and entomology (Castillero, 2004). That period was also marked by the establishment of a field station of the Smithsonian Institution (1923), financed by the US government, that in 1966 became the Smithsonian Tropical Research Institute, STRI (STRI, http://goo.gl/jBsfTV). In the decade of 1970 Panama was impacted by the international awareness that tropical ecosystems are the most bio-diverse in the planet, and possibly also among the most endangered (Leigh, Rand \& Windsor, 1982). Both the Panamanian research institutions and STRI started to focus in understanding and protecting the country's ecosystems, a focus that continues today. As happened to similar efforts in other countries, the $21^{\text {st }}$ century is characterized by a growing interest in the commercial use of biodiversity, with the goal of sustainable development (Dettenhofer \& Hampl, 2009).

Apparently there are no scientometric studies focused on Panama, but the country has been mentioned in a few regional studies. At the Latin American level, Panama produces $4 \%$ of all documents about the systematics of tropical organisms (Michan \& Llorente-Bousquets, 2010) and has an important production of documents about Chagas disease (Ramos et al., 2011). Nevertheless, Panama also is one of the countries in the region where epidemiological studies had the lowest growth rate in recent years (Barreto et al., 2012).

In this article we analyze publication type, language, main fields of research, and most visible authors and institutions for the part of scientific publications originating in Panama that are included in the Science Citation Index Expanded. It is part of a series about scientific output in Mesoamerican countries (MongeNájera \& Ho, 2012).

\section{MATERIALS AND METHODS}

The data were based on the online version of the Science Citation Index Expanded (SCI-EXPANDED). According to Journal Citation Reports (JCR), it indexes 8539 journals with citation references across 176 scientific disciplines in the science edition in 2013. All documents with "Panama" in the address field from 1980 to 2013 were considered and refined by countries/territories as Panama. In total, 4854 publications met the selection criteria. Document information included names of authors, title, year of publication, source journals publishing the articles, contact address, and each year citation times for every publication were downloaded into Microsoft Excel software, and additional coding was manually performed for origin country and institute of the collaborators and impact factors of the publishing journals. Besides, the reported impact factor (IF) of each journal was obtained from the 2013 JCR. Collaboration type was determined by the addresses of the authors, where the term "internationally collaborative article" was assigned to those articles that were coauthored by researchers from outside of Panama. Articles originating from England, Scotland, Northern Ireland, Wales, and West Indies Associated States were reclassified as originating from the United Kingdom (UK). Similarly, articles from Reunion, New Caledonia, Martinique, French Guiana, and French Polynesia were included in France. Federal Republic of Germany (Fed Rep Ger) and Germany were reclassified as being from Germany (Ho, 2012). Articles from Hong Kong were included under the heading of China but not as a separate territory for consistency (Chuang et al., 2011). Articles from USSR and Russia (Ho, 2012), Yugoslavia and Croatia (Ho, 2013), Czechoslovakia and Czech Republic (Ho, 2013), were reclassified as being from Russia, Croatia, and Czech Republic respectively. In addition, articles from Zaire were recognized to be Congo and Democratic Republic of the Congo. The term "institute independent article" was assigned if the researchers' addresses were from the same institute in Panama. The term "inter-institutionally collaborative article" was assigned if authors were from different institutes (Li \& Ho, 2008). All the articles referring to "Panama" were assessed by the following aspects: document type and language of publications, characteristics of article outputs, 
distribution of output in subject categories and journals, article outputs of institute and collaborative country. The total number of citations was recorded on 30 January 2015. Total citation times from publication to 2013 in the Web of Science Core Collection is presented as $T C_{2013}$ (Wang et al., 2010). The bibliometric impact of a publication is usually assessed in terms of the number of citations it has received relative to other outputs in the same journal or field. Citations per publication $(C P P)$ was another indicator which was defined as the total citations from Web of Science Core Collection since publication to year $2013\left(T C_{2013}\right)$ per publication (Fu et al., 2012).

\section{RESULTS}

The oldest records in the SCI-EXPANDED are reports on treatment of amebic dysentery and on malarial infection in Panamanian villages (Curl, 1906; Kendall, 1906). The majority of Panama publications recorded by the SCIEXPANDED are formal articles, with meeting

\section{TABLE 1}

Proportion of Panama publications of each type in the Science Citation Index Expanded (total 4854 publications)

\begin{tabular}{lccc}
\multicolumn{1}{c}{ Document type } & $\%$ & $T C_{2013}$ & $C P P$ \\
Article & 82 & 106063 & 27 \\
Meeting abstract & 6.4 & 65 & 0.21 \\
Review & 3.8 & 17692 & 95 \\
Editorial material & 2.7 & 2353 & 18 \\
Letter & 2.6 & 972 & 7.8 \\
Proceedings paper & 2.3 & 5118 & 47 \\
Note & 1.8 & 1445 & 16 \\
Correction & 0.29 & 22 & 1.6 \\
Book chapter & 0.27 & 655 & 50 \\
Book review & 0.27 & 3 & 0.23 \\
Biographical-item & 0.082 & 1 & 0.25 \\
News item & 0.082 & 5 & 1.3 \\
Item about an individual & 0.041 & 1 & 0.50 \\
Reprint & 0.041 & 12 & 6.0 \\
Discussion & 0.021 & 0 & 0 \\
\hline
\end{tabular}

$T C$ : total citations since publication to the end of 2013 from Web of Science Core Collection; $C P P: T C_{2013}$ per publication. abstracts and reviews in distant second and third places. The most cited document types are reviews followed by book chapters, proceedings papers, and articles (Table 1). Only 3974 original articles were used for further analysis. Nearly all articles in the database are in English (97\% of 3974 articles), with a very small proportion in other languages (all in \%): Spanish 2.2; Portuguese 0.18; French 0.10; German 0.050 ; Hungarian 0.050, and Italian 0.025.

The local Panamanian production is mainly in the fields of ecology, botany, zoology, evolution and aquatic biology. The main STRI fields are the same but in different order, with more articles on evolution and less on botany (Table 2; a file with only STRI data is available from the authors).

There is no difference between Panamanian and STRI researchers for the countries with which they have collaboration leading to joint publications. They mostly work with scientists from the USA, Germany, United

\section{TABLE 2}

Top 20 productive subject categories of Panama articles in the Science Citation Index Expanded (total 4854 publications)

\begin{tabular}{|c|c|}
\hline Subject category & $\%$ \\
\hline Ecology & 28 \\
\hline Plant sciences & 11 \\
\hline Zoology & 10 \\
\hline Evolutionary biology & 10 \\
\hline Marine \& freshwater biology & 6.9 \\
\hline Biology & 6.8 \\
\hline Multidisciplinary sciences & 6.2 \\
\hline Entomology & 5.7 \\
\hline Genetics \& heredity & 4.9 \\
\hline Biochemistry \& molecular biology & 4.8 \\
\hline Behavioral sciences & 4.1 \\
\hline Environmental sciences & 3.8 \\
\hline Pharmacology \& pharmacy & 3.7 \\
\hline Biodiversity conservation & 3.5 \\
\hline Tropical medicine & 2.8 \\
\hline Medicinal chemistry & 2.8 \\
\hline Public, environmental \& occupational health & 2.7 \\
\hline Multidisciplinary geosciences & 2.4 \\
\hline Infectious diseases & 2.4 \\
\hline Forestry & 2.2 \\
\hline
\end{tabular}


Kingdom, Canada, and Brazil (Table 3). The most productive institutes are STRI, the University of Panama, the Gorgas Institute, the Children's Hospital, the Institute of Scientific Research and Advanced Technology Services, the Technological University of Panama, the Ministry of Health and the University of Chiriquí (Table 4).

The majority of the scientists highly cited in American and European journals are STRI zoologists, ecologists, and botanists. The exception is G. Zots, a forest ecologist from the University of Oldenburg in Germany who publishes mostly about epiphytes. The only Latin American in the list is Héctor Guzmán, a Venezuelan zoologist who specializes in coral biology; the only woman, E. Kalko, a German bat expert (Table 5).

Title and keyword terms are indicators of research trends and show a concentration

TABLE 3

Top 15 collaborative countries for Panama articles in the Science Citation Index Expanded (1980 2013)

\begin{tabular}{lcccc}
\multicolumn{1}{c}{ Country } & $C A$ & $C A$ Rank $(\%)$ & $F A$ Rank $(\%)$ & $R A$ Rank $(\%)$ \\
USA & 2149 & $1(54)$ & $1(3.8)$ & $1(33)$ \\
Germany & 421 & $2(11)$ & $2(3.0)$ & $2(5.8)$ \\
UK & 360 & $3(9.1)$ & $3(2.7)$ & $3(3.9)$ \\
Canada & 267 & $4(6.7)$ & $5(1.7)$ & $5(2.8)$ \\
Brazil & 244 & $5(6.1)$ & $9(1.0)$ & $8(1.6)$ \\
Spain & 232 & $6(5.8)$ & $4(1.8)$ & $4(3.0)$ \\
Colombia & 194 & $7(4.9)$ & $10(0.91)$ & $11(1.1)$ \\
Australia & 187 & $8(4.7)$ & $8(1.1)$ & $7(1.7)$ \\
Costa Rica & 178 & $9(4.5)$ & $7(1.6)$ & $9(1.3)$ \\
Mexico & 163 & $10(4.1)$ & $11(0.70)$ & $10(1.1)$ \\
Switzerland & 151 & $11(3.8)$ & $16(0.50)$ & $6(1.9)$ \\
France & 113 & $12(2.8)$ & $12(0.68)$ & $16(0.55)$ \\
Japan & 95 & $13(2.4)$ & $13(0.65)$ & $14(0.63)$ \\
Argentina & 91 & $14(2.3)$ & $17(0.45)$ & $13(0.69)$ \\
Venezuela & 91 & $14(2.3)$ & & $19(0.45)$ \\
\hline
\end{tabular}

$C A$ : internationally collaborative articles with Panama; $F A$ : article with first author; $R A$ : article with corresponding author; $\%$ : share in their total Panama articles.

TABLE 4

Top 10 institutions for Panama articles in the Science Citation Index Expanded

\begin{tabular}{|c|c|c|c|c|c|}
\hline Institute & $T P$ & $S A(\%)$ & $C A(\%)$ & $F A(\%)$ & $R A(\%)$ \\
\hline Smithsonian Tropical Research Institute & 2860 & 12 & 88 & 34 & 29 \\
\hline University of Panama & 510 & 12 & 88 & 34 & 29 \\
\hline Hospital del Niño & 175 & 10 & 90 & 35 & 18 \\
\hline Gorgas Memorial Laboratory & 100 & 17 & 83 & 45 & 22 \\
\hline Inst Invest Cient \& Serv Alta Tecnol & 78 & 0 & 100 & 31 & 32 \\
\hline Gorgas Memorial Laboratory & 70 & 19 & 81 & 47 & 40 \\
\hline Technological University of Panama & 67 & 7.5 & 93 & 43 & 43 \\
\hline Gorgas Memorial Institute for Health Studies & 58 & 19 & 81 & 50 & 38 \\
\hline Minister of Health & 53 & 7.5 & 92 & 25 & 13 \\
\hline Universidad Autónoma de Chiriquí & 29 & 10 & 90 & 21 & 17 \\
\hline
\end{tabular}

$T A$ : total articles; $S A$ : single institute articles; $C A$ : inter-institutionally collaborative articles; $F A$ : article with first author; $R A$ : article with corresponding author; $R$ : rank; \%: percentage per institute. 
TABLE 5

Top 20 authors for Panama articles in the Science Citation Index Expanded

\begin{tabular}{|c|c|c|c|c|}
\hline Author & $T A$ Rank $(T A)$ & $F A$ Rank $(F A)$ & $R A$ Rank $(R A)$ & $S A$ Rank $(S A)$ \\
\hline Gupta, M.P. & $1(126)$ & $145(4)$ & $8(24)$ & $72(1)$ \\
\hline Wright, S.J. & $2(124)$ & $3(27)$ & $6(26)$ & $11(6)$ \\
\hline Bermingham, E. & $3(119)$ & $343(2)$ & $110(5)$ & N/A \\
\hline Kalko, E.K.V. & $4(110)$ & $40(10)$ & $15(18)$ & $45(2)$ \\
\hline Winter, K. & $5(100)$ & $15(16)$ & $10(22)$ & N/A \\
\hline Ryan, M.J. & $6(92)$ & $15(16)$ & $15(18)$ & $33(3)$ \\
\hline Turner, B.L. & $7(90)$ & $7(23)$ & $8(24)$ & $14(5)$ \\
\hline Guzmán, H.M. & $8(88)$ & $2(32)$ & $2(36)$ & $33(3)$ \\
\hline Zotz, G. & $9(76)$ & $1(43)$ & $1(47)$ & $7(8)$ \\
\hline Dudley, R. & $10(72)$ & $10(19)$ & $12(20)$ & $4(9)$ \\
\hline Rand, A.S. & $11(70)$ & $77(6)$ & $82(6)$ & $45(2)$ \\
\hline Laurance, W.F. & $12(65)$ & $3(27)$ & $3(33)$ & $7(8)$ \\
\hline Wcislo, W.T. & $13(64)$ & $25(13)$ & $15(18)$ & $11(6)$ \\
\hline Roubik, D.W. & $14(61)$ & $6(24)$ & $7(25)$ & $2(10)$ \\
\hline Hubbell, S.P. & $15(57)$ & $77(6)$ & $110(5)$ & $45(2)$ \\
\hline Ortega-Barria, E. & $16(51)$ & N/A & $312(2)$ & N/A \\
\hline Robertson, D.R. & $16(51)$ & $18(14)$ & $24(15)$ & $7(8)$ \\
\hline Lessios, H.A. & $18(50)$ & $3(27)$ & $4(31)$ & $1(11)$ \\
\hline Jackson, J.B.C. & $19(49)$ & 25 (13) & $34(12)$ & $14(5)$ \\
\hline Herre, E.A. & 19 (49) & 77 (6) & 47 (9) & $23(4)$ \\
\hline
\end{tabular}

$T A$ : Total articles; $F A$ : article with first author; $R A$ : article with corresponding author; $S A$ : single author articles; $R$ : rank.

on tropical forest trees, diversity and variation, considering mostly the effects of particular physical and biological causes (Digital Appendice 1, Digital Appendice 2 and Digital Appendice 3).

The historical trend in output shows a strong growth in the last decades and no plateau (Fig. 1A). The SCI-EXPANDED citations remain relatively stable and only fall in the last decade (Fig. 1B). There is a strong peak of citations in 1995 produced by one particular article on papillomavirus: Bosch et al. (1995).

Ecology grew strongly and there was a smaller increase in plant sciences and evolutionary biology. Output in marine biology, freshwater biology and general biology has been relatively constant (Fig. 2 and Fig. 3).

Collaboration with other institutions in the production of articles grows parallel to total output (Fig. 4). The most SCI-EXPANDED cited articles are from STRI, the University of Panama and health research institutions (Children's Hospital, Gorgas, and IICSAT; Fig. 5). Note: Figs. 5 through 9 are in Digital Appendix 4); they are mostly studies about tropical ecology and health-related subjects (Fig. 7 and Fig. 8).

The lifespan of articles exceeds 20 years, with top effect four years after publication (Fig. 9).

\section{DISCUSSION}

The great majority of Panama publications in the SCI-EXPANDED are formal articles. A probable reason is that, normally, institutions do not offer financial incentives for the publication of smaller works such as comments, letters and book reviews, so authors concentrate their efforts in the publication of full articles. The same trend was found by Ramos et al. (2011) who reported that $89 \%$ of Latin American 

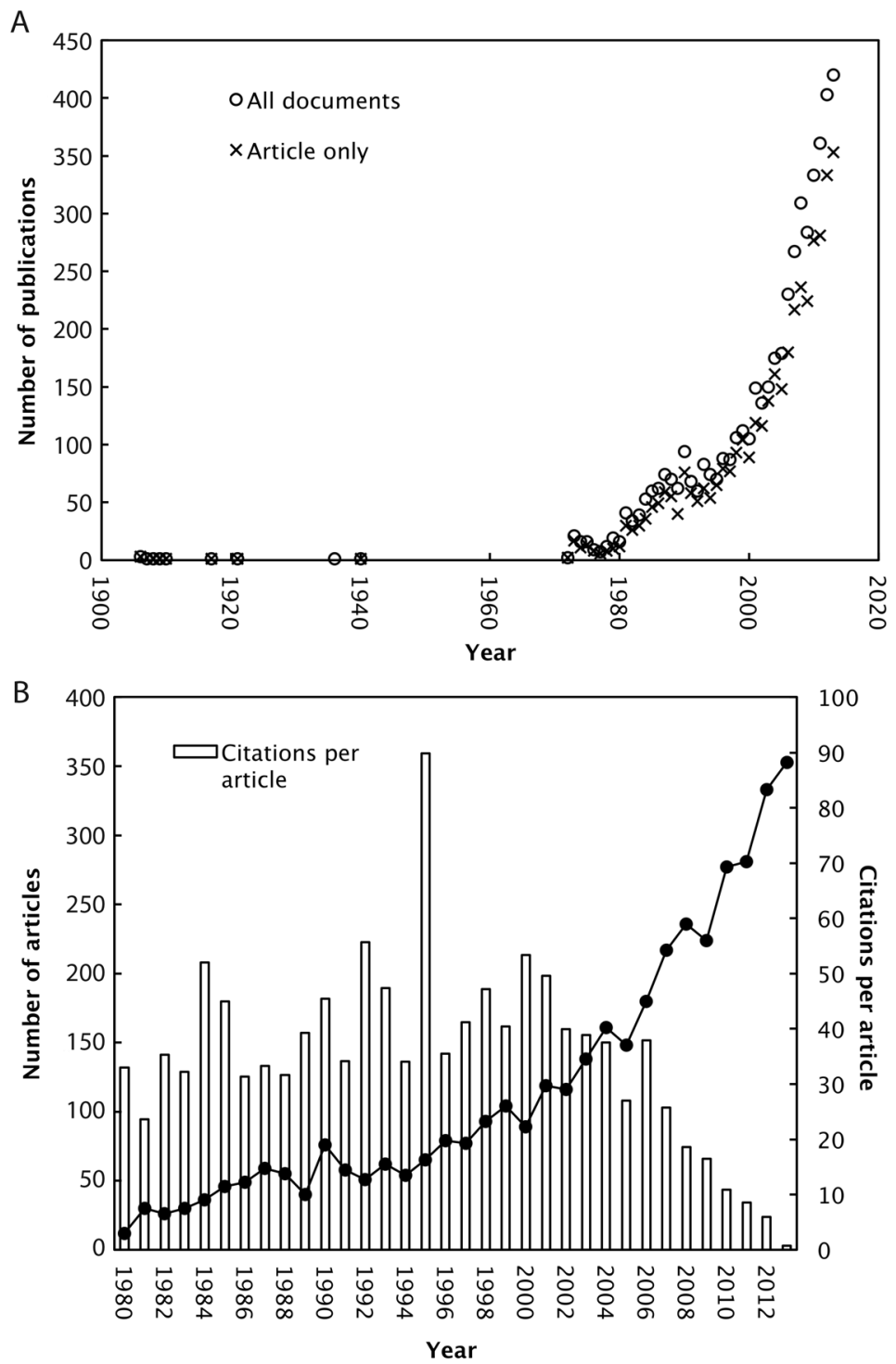

Fig. 1. Trend of the number of publications referring to Panama in the Science Citation Index Expanded. A Number of publications since 1900. B Citations versus articles after 1979.

studies on Chagas disease were articles, while reviews and letters only amounted to $8 \%$. This seems to be a general trend worldwide (Chiu \& Ho, 2005). Nevertheless, materials such as book chapters and reviews receive more citations than articles, possibly because they are of more general interest.

Nearly all articles in this particular database are in English, also in agreement with other studies based on the data of the SCIEXPANDED. For example, $76 \%$ of publications about Chagas disease are in English, 11 $\%$ in Portuguese and $9 \%$ in Spanish (Ramos et al., 2011). However, this result can be misleading because most of the papers written in Spanish, which represent a considerable number, are published in journals not covered by the SCI-EXPANDED. This limitation has been 


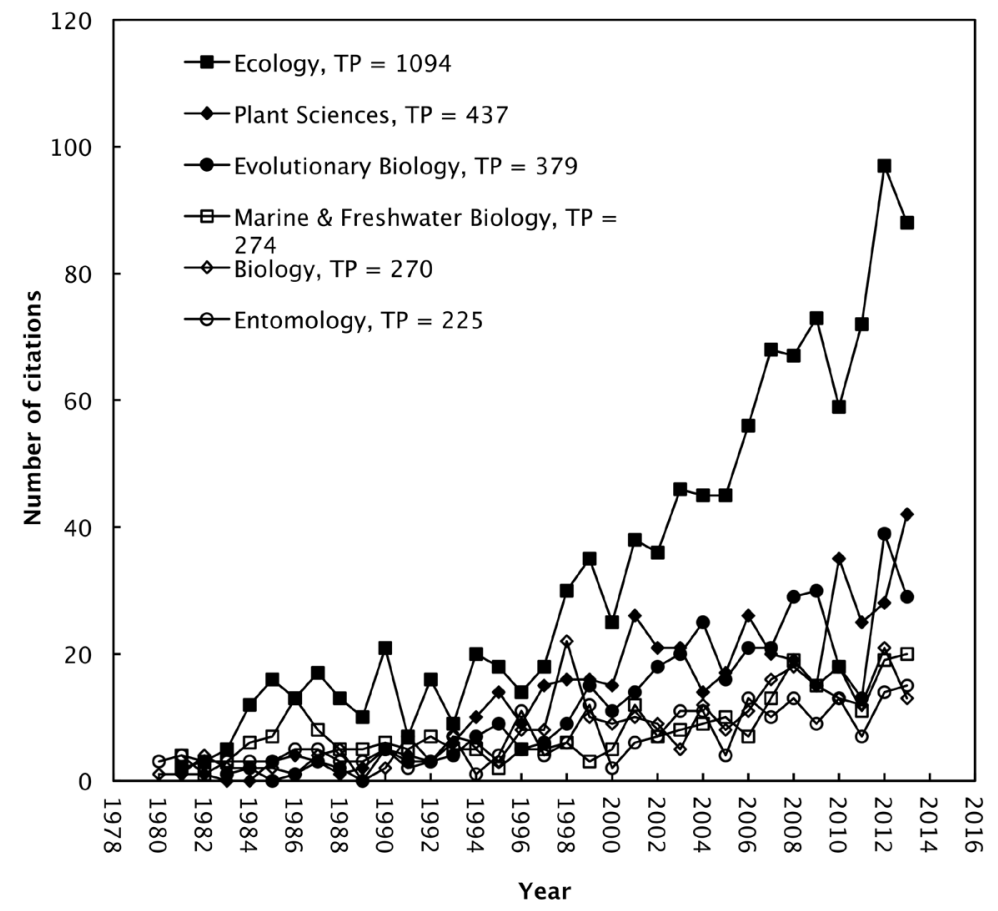

Fig. 2. Trends of the top six productive subject categories for Panama in the Science Citation Index Expanded.

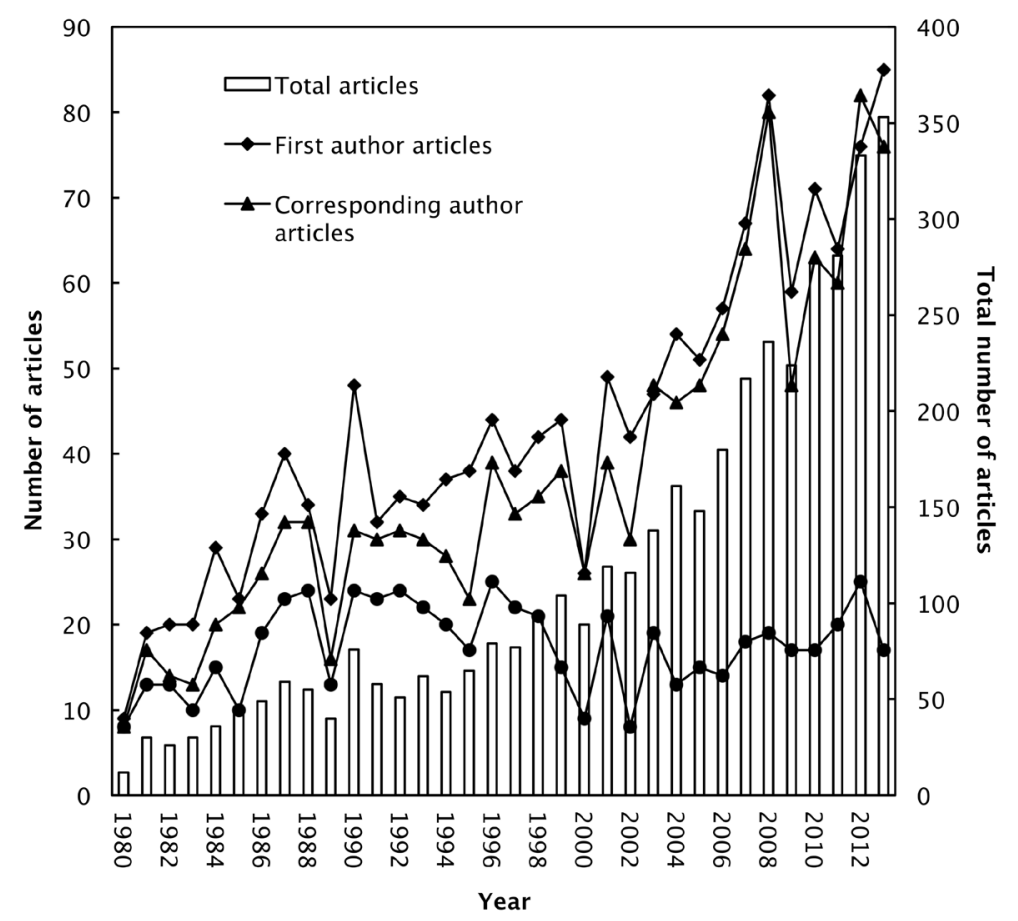

Fig. 3. Distribution of articles by Panama authors in the Science Citation Index Expanded. 


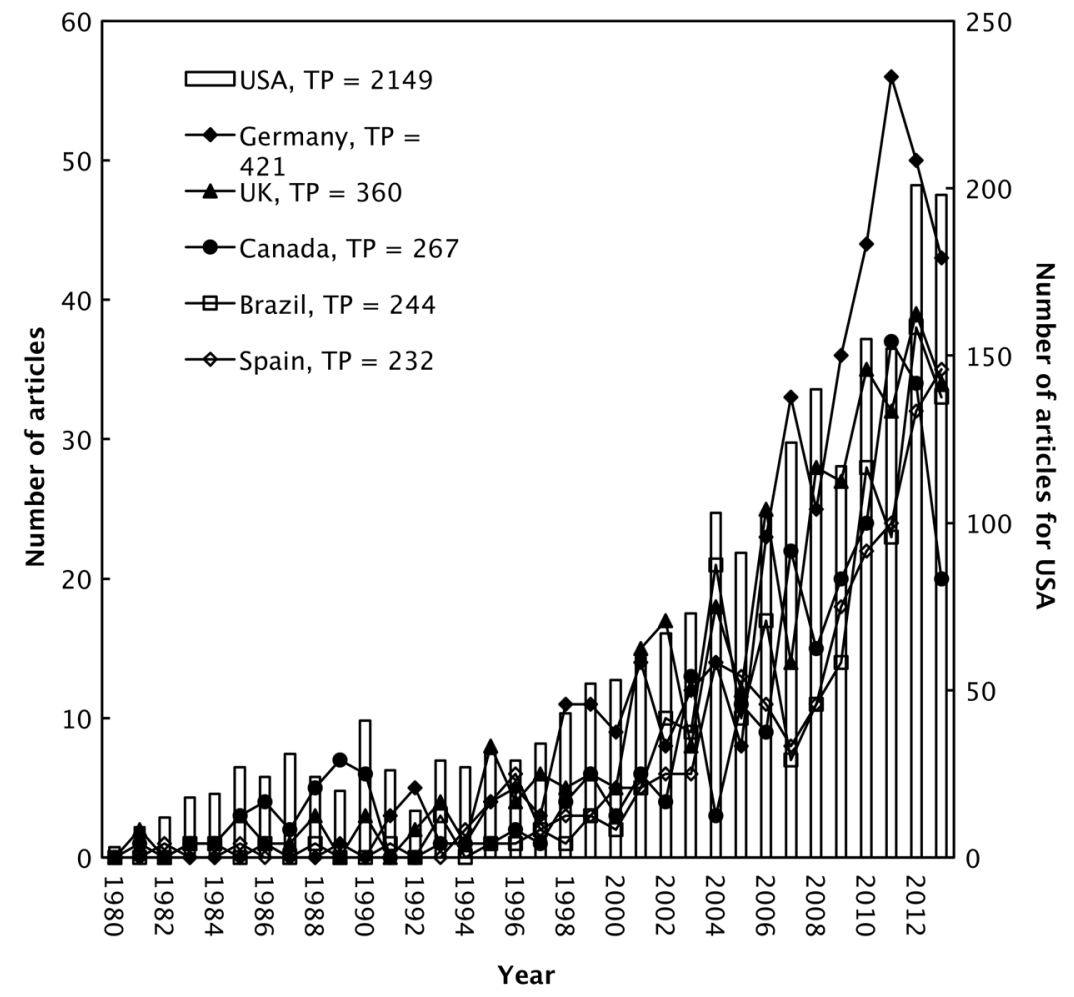

Fig. 4. Top six countries that publish in collaboration with Panama for articles included in the Science Citation Index Expanded.

pointed out before by several authors including Monge-Nájera and Nielsen (2005) and Michan \& Llorente-Bousquets (2010).

The emphasis in ecology, botany, zoology and evolution and aquatic biology is similar to results from studies in nearby countries. Research oriented on the needs of Latin American countries focuses on plant physiology and pathology, soil ecology, animal taxonomy, biomedicine and general ecology (Monge-Nájera \& Díaz, 1988; Barrientos \& Monge-Nájera, 1990), but biology in general is dominated on land by ecological and systematics studies of animals followed by plants (29\%) and quite distantly by fungi (Nielsen-Muñoz et al., 2012; Monge-Nájera et al., 2013, Nielsen \& Azofeifa, 2013). The trend is similar in freshwater and marine studies, usually dominated by animal ecology with far lower numbers for plants, fungi and other organisms (Cortés \& Nielsen, 2002).

Panama collaboration is done mostly with countries that meet two criteria: they have a large scientific infrastructure and are located in a geographically related region (MongeNájera \& Nielsen, 2005). This matches the trend found for other Latin American countries in several fields: Chagas disease (Ramos et al., 2011), Central American biodiversity (Costa Rica) (Nielsen-Muñoz et al., 2012), biological research in neighboring Costa Rica (MongeNájera \& Ho, 2012) and a general trend of countries with the larger scientific communities being more influential (Chiu \& Ho, 2005).

The most productive Panamanian institutions are public institutions financed by the Panamanian government: University of Panama, Gorgas Institute, Children's Hospital, 
Technological University of Panama, Ministry of Health and University of Chiriquí. The exception is the Institute for Scientific Research and Advanced Technology Services, a private organization that studies natural sources for new drugs, a field in which there is usually good financing (Dettenhofer \& Hampl, 2009). Generally, institutional performance is a product of internal factors and relationships with other institutions (Wang, Fu \& Ho, 2010; 2011). It is not surprising that STRI appears as the most productive institute, because its researchers are carefully selected and have access to infrastructure and resources from the US government and to the English language journals covered by ISI (basically American and European journals; see the bibliographies in Leigh, Rand and Windsor (1982) and STRI: http://goo.gl/1u7NTt). Research published in Panamanian journals is not included in the ISI database (Latindex, http://goo.gl/iLwtvS) and are not included in our study, but this does not mean that they are less important. They might in fact publish more articles than SCIEXPANDED journals, but this information is not currently available.

As usual in small countries, much Panamanian research is applied to health problems and can be considered technologically oriented. That is why the most productive institutions are medical institutions such as the Children's Hospital (http://www.hn.sld.pa/) and the Gorgas Institute (www.gorgas.gob.pa). The ecology and conservation of tropical ecosystems represent the other large research field, mainly studied by the public universities (http://www. up.ac.pa/vip/). Despite previously being a small branch of the University of Panama that only recently became independent, the University of Chiriquí appears among the most productive in the country, possibly because of its aggressive research program (http://www.unachi.ac.pa/) led by Costa Rica-trained scientists (JMN personal observation).

Citation can be an indicator of many aspects of scientific output, including productivity, research collaboration and emerging fields (Fu, Wang \& Ho, 2012; Chuang, Wang
\& Ho, 2011; Ho 2012, 2013, Nielsen \& Azofeifa, 2013). There are no studies about why individual researchers in Panama are so influential in their fields but in a similar case, that of Central American botanist L.D. Gómez, it was found that success was related with innovation in research subjects and selection of topics of general interest that could be studied with few resources (Monge-Nájera et al., 2010).

The dominance of male researchers among the top cited scientists in the SCI-EXPANDED does not correspond with the large proportion of female researchers in STRI. However, most women doing research in that institution are visiting or student researchers. Apparently, only tenured STRI staff, dominated by male zoologists, ecologists and botanists (STRI, http:// goo.gl/1u7NTt) has the conditions required to publish in journals that are highly cited in the SCI-EXPANDED.

It is not surprising that the top cited articles are studies in topics of general interest, i.e. cancer (Bosch et al., 1995) and the value of marine biodiversity (Worm et al., 2006) plus following comments by Hölker et al. (2007), Jaenike (2007), and Wilberg and Miller (2007) and response to comments by Worm et al. (2007). Worm's team paper was studied by Branch (2013) who concluded that the large number of citations resulted from an alarmist claim in the article. That claim received much media coverage and thus the attention of many authors not familiar with expert rebuttals that were published shortly after the original article. Curiously, that weakness of the study inflated its impact for many years (Branch, 2013) and should be a warning to anyone taking citation at face value.

Keyword trends indicate the growing interest of research institutions in the ecological constitution, function and conservation of tropical ecosystems, and agrees with studies in nearby countries (Monge-Nájera \& Ho, 2012; Albuquerque et al., 2013; MongeNájera et al., 2013).

The strong growth in productivity since 1970 probably shows a real pattern, i.e. the number of researchers grows as the population 
grows; furthermore, increasing awareness of the importance of research leads to better financing and better trained scientists in many countries. But it can also be caused by efforts in the SCI-EXPANDED to increase the number of Latin American journals it covers now that its methods are increasingly under criticism (Monge-Nájera, 2014). In any case the increasing number of publications parallels a general growth of scientific output in most of Latin America (Michan \& Llorente-Bousquets, 2010; Ramos et al., 2011; Barreto et al., 2012).

The decline in citations after 2006 probably shows that there has not been enough time for more recent articles to be cited. In the field of tropical ecology that dominates Panamanian production, longer periods are needed for the accumulation of citations. The cause of the peak of citations in 1995 seems to be the general importance and wide coverage of the study by Bosch et al. (1995) on cervical cancer, the second most common cancer in women worldwide (World Health Organization; http://goo. gl/P4rywS).

Even though it may appear that collaboration is growing in recent decades, the growth of collaboration matches the growth in scientific output, so proportionally there is no real increase. This is different from neighboring countries (Nielsen-Muñoz et al., 2012) and may simply indicate that the arrival of American researchers a century ago led to early establishment of collaborative research in Panama.

The long lifespan of articles (over two decades) may result from the relatively low number of scientists working in the tropics and the frequent need of long periods to study ecological phenomena in the tropics (Leigh, Rand, \& Windsor, 1982; Li \& Ho, 2008). The fact that most citations occur four years after publication, i.e. two years after the SCI-EXPANDED stops counting to produce the Impact Factor, shows that the Impact Factor as currently measured is not appropriate to know the impact of tropical research. This also supports previous findings by other authors (Michan \& LlorenteBousquets, 2010; Monge-Nájera \& Ho, 2012; Monge-Nájera, 2014).
Panama has nearly 100 scientific journals that are not taken into account by the SCIEXPANDED (Latindex, http://goo.gl/iLwtvS) and we are aware that our study does not cover the most common research fields, the productivity of authors and institutions or the impact of research published in those Panamanian journals. Nevertheless we believe that our results offer a valuable baseline to future studies that, hopefully, will include more of the Latin American literature that deals more closely with research in Panama.

\section{ACKNOWLEDGMENTS}

We thank Héctor Guzmán (Smithsonian, Panama) for useful information.

\section{RESUMEN}

Bibliometría de las publicaciones de Panamá en el Índice de Citación Expandido de Ciencia: tipo de publicación, idioma, temáticas, autores e instituciones. Panamá es un pequeño país de América Central del que aparentemente no existen estudios cienciométricos específicos. Analizamos 4854 documentos de investigación procedentes de Panamá en el Science Citation Index Expanded (SCI-Expanded). La mayoría son artículos formales y casi todos están en inglés. Los principales campos son ecología, botánica, zoología, evolución y biología acuática. La mayor colaboración se realiza con EE.UU., Alemania, Reino Unido, Canadá y Brasil y el mayor número de artículos son publicados por el Instituto Smithsonian de Investigaciones Tropicales, la Universidad de Panamá, el Instituto Gorgas, el Hospital de Niños, el Instituto de Investigación Científica y Servicios Avanzados de Tecnología, la Universidad Tecnológica de Panamá, el Ministerio de Salud y la Universidad de Chiriquí. Las palabras clave muestran una concentración temática en árboles del bosque tropical, diversidad y variación orgánica (especialmente los efectos de causas físicas y biológicas). La producción ha crecido de manera constante desde hace varias décadas y continúa aumentando. Las citas en el SCI-Expanded se mantienen relativamente estables y la vida útil de los artículos supera los 20 años, con la mayoría de esas citas en los cuatro años posteriores a su publicación. El factor de impacto como se mide en la actualidad no es apropiado para conocer el impacto de la ciencia panameña, pues Panamá cuenta con cerca de 100 revistas científicas que no son tomados en cuenta por SCI-Expanded. Por ello, la productividad total de autores e instituciones, y su impacto, se desconocen, pero nuestros datos representan un punto de partida válido para la investigación futura. 
Palabras clave: Panamá, SCI-EXPANDED, Web of Science, tendencias de investigación.

\section{REFERENCES}

Albuquerque, U., Soares, S., Almeida, A., Silva, R., Cristina Silva, C., \& Nóbrega, R. (2013). The current status of ethnobiological research in Latin America: gaps and perspectives. Journal of Ethnobiology and Ethnomedicine, 9(72), 2-9.

Barreto, S. M., Miranda, J. J., Figueroa, J. P., Schmidt, M. I., Muñoz, S., Kuri-Morales, J. P., \& Silva Jr., J. B. (2012). Epidemiology in Latin America and the Caribbean: current situation and challenges. International Journal of Epidemiology, 41, 557-571.

Barrientos, Z. \&. Monge-Nájera, J. (1990). Los 40 años de la Revista Turrialba: Un análisis de los artículos publicados en ese período. Turrialba, 40(1), 1-4.

Bosch, F. X., Manos, M. M., Munoz, N., Sherman, M., Jansen, A. M., Peto, J., Schiffman, M. H., Moreno, V., Kurman, R., Shah, K. V., Alihonou, E., Bayo, S., Mokhtar, H. C., Chicareon, S., Daudt, A., de los Rios, E., Ghadirian, P., Kitinya, J. N., Koulibaly, M., Ngelangel, C., Tintore, L. M. P., Rios-Dalenz, J. L., Sarjadi, Schneider, A., Tafur, L., Teyssie, A. R., Rolon, P. A., Torroella, M., Tapia, A. V., Wabinga, H. R., Zatonski, W., Sylla, B., Vizcaino, P., Magnin, D., Kaldor, J., Greer, C., \& Wheeler, C. (1995). Prevalence of human papillomavirus in cervical cancer: A worldwide perspective. Journal of the National Cancer Institute, 87(11), 796-802.

Branch, T. A. (2013). Citation patterns of a controversial and high-impact paper: Worm et al., (2006) "Impacts of biodiversity loss on ocean ecosystem services". PLoS One, 8(2), Article Number: e56723.

Castillero, C. A. (2004). Editor. Historia General de Panamá. Panama: Ministerio de la Presidencia.

Chiu, W. T. \& Ho, Y. S. (2005). Bibliometric analysis of homeopathy research during the period of 1991 to 2003. Scientometrics, 63(1), 3-23.

Chuang, K. Y., Wang, M. H. \& Ho, Y. S. (2011). Highimpact papers presented in the subject category of water resources in the Essential Science Indicators database of the Institute for Scientific Information. Scientometrics, 87(3), 551-562.

Cortés, J. \& Nielsen, V. (2002). Las ciencias del mar en la Revista de Biología Tropical en su 50 aniversario. Revista de Biología Tropical, 50(4), 903-907.

Curl, H. C. (1906). The relative value of cecostomy and appendostomy in the treatment of amebic dysentery by irrigation of the colon. Annals of Surgery, 43, 543-546.
Dettenhofer, M \& Hampl, N. (2009). Development of a biomedical innovation economy-Panama. Journal of Technology Management \& Innovation, 4(2), 21-32.

Fu, H. Z., Wang, M. H. \& Ho, Y. S. (2012). The most frequently cited adsorption research articles in the Science Citation Index (Expanded). Journal of Colloid and Interface Science, 379(1), 148-156.

Ho, Y. S. (2012). Top-cited articles in chemical engineering in Science Citation Index Expanded: A bibliometric analysis. Chinese Journal of Chemical Engineering, 20(3), 478-488.

Ho, Y. S. (2013). The top-cited research works in the Science Citation Index Expanded. Scientometrics, 94(3), 1297-1312.

Hölker, F., Beare, D., Dörner, H., di Natale, A., Rätz, H. J., Temming, A., \& Casey, J. (2007). Comment on "Impacts of biodiversity loss on ocean ecosystem services". Science, 316 (5829), 1285.

Jaenike, J. (2007). Comment on "Impacts of biodiversity loss on ocean ecosystem services". Science, $316(5829), 1285$.

Kendall, A. I. (1906). Malarial infection in certain native villages of the Canal Zone. JAMA-Journal of the American Medical Association, 46, 1151-1154.

Leigh, E. G., Rand, A. S., \& Windsor, D. M. (Eds.) (1982). The Ecology of a Tropical Forest. Washington D.C.: Smithsonian Institution.

Li, Z., \& Ho, Y. S. (2008). Use of citation per publication as an indicator to evaluate contingent valuation research. Scientometrics, 75(1), 97-110.

Michán, L., \& Llorente-Bousquets, J. (2010). Bibliometría de la sistemática biológica sobre América Latina durante el siglo XX en tres bases de datos mundiales. Revista de Biología Tropical, 58(2), 531-545.

Monge-Nájera, J., \& Díaz, L. (1988). Thirty-five years of Tropical biology: a quantitative history. Revista de Biología Tropical, 36(2B), 347-359.

Monge-Nájera, J., \& Nielsen, V. (2005).The countries and languages that dominate biological research at the beginning of the 21 st century. Revista de Biologia Tropical, 53, 283-294.

Monge-Nájera, J. (2014). La invalidez del Factor de Impacto como indicador del impacto de las revistas científicas latinoamericanas. Revista de Biología Tropical, 62 (1), 407-412.

Monge-Nájera, J., \& Ho, Y. S. (2012). Costa Rica publications in the Science Citation Index Expanded: A bibliometric analysis for 1981-2010. Revista de Biología Tropical, 60(4), 1649-1661.

Monge-Nájera, J., Nielsen-Muñoz, V., \& Azofeifa-Mora, A. B. (2013). Subject and authorship of records related to the Organization for Tropical Studies (OTS) in BINABITROP, a comprehensive database about 
Costa Rican biology. Revista de Biología Tropical, 61(2), 859-873.

Monge-Nájera, J., Nielsen, V., \& Azofeifa, A. (2010). Determinants of scientific output: an in-depth view of the productivity of tropical botanist and conservationist, Luis Diego Gómez Pignataro. Revista de Biología Tropical, 58(4), 1093-1114.

Nielsen, V., Azofeifa, A., \& Monge-Nájera, J. (2012). Bibliometry of Costa Rica biodiversity studies published in the Revista de Biología Tropical/International Journal of Tropical Biology and Conservation (20002010): the content and importance of a leading tropical biology journal in its $60^{\text {th }}$ Anniversary. Revista de Biología Tropical, 60(4), 1-9.

Nielsen, V. \& Azofeifa, A. (2013). Informe Estado de la Ciencia, Tecnología e Innovación. Análisis de la producción científica y tecnológica en Costa Rica: 2001-2011. Santos, M. \& García, I. (Eds.). Investigación Final. Retrieved from http://kerwa.ucr.ac.cr/ handle/10669/11120

Ramos, J. M., González-Alcaide, G., Gascón, J., \& Gutiérrez, F. (2011). Mapping of Chagas disease research: Analysis of publications in the period between 1940 and 2009. Revista da Sociedade Brasileira de Medicina Tropical, 44(6), 708-716.
Wang, M. H., Fu, H. Z., \& Ho, Y. S. (2011). Comparison of universities' scientific performance using bibliometric indicators. Malaysian Journal of Library \& Information Science, 16(2), 1-19.

Wang, M. H., Yu, T. C., \& Ho, Y. S. (2010). A bibliometric analysis of the performance of Water Research. Scientometrics, 84(3), 813-820.

Wilberg, M. J., \& Miller, T. J. (2007). Comment on "Impacts of biodiversity loss on ocean ecosystem services”. Science, 316(5829), 1285.

Worm, B., Barbier, E. B., Beaumont, N., Duffy, J. E., Folke, C., Halpern, B. S., Jackson, J. B. C., Lotze, H. K., Micheli, F., Palumbi, S. R., Sala, E., Selkoe, K. A., Stachowicz, J. J., \& Watson, R. (2007). Response to comments on "Impacts of biodiversity loss on ocean ecosystem services". Science, 316(5829), 1285-1286.

Worm, B., Barbier, E. B., Beaumont, N., Duffy, J. E., Folke, C., Halpern, B. S., Jackson, J. B. C., Lotze, H. K., Micheli, F., Palumbi, S. R., Sala, E., Selkoe, K. A., Stachowicz, J. J., \& Watson, R. (2006). Impacts of biodiversity loss on ocean ecosystem services. Science, 314(5800), 787-790.

\section{Note:}

\section{Digital Appendix 1 - Digital Appendix 2 - Digital Appendix 3 Digital Appendix 4 (Figs. 5 through 9) in attachments.}

